\title{
Spiral multiple-effect diffusion solar still coupled with vacuum-tube collector and heat pipe
}

\author{
Bin-Juine Huang a,*, Tze-Ling Chong ${ }^{\mathrm{b}}$, Po-Hsien $\mathrm{Wu}^{\mathrm{a}}$, Han-Yi Dai ${ }^{\mathrm{a}}$, Yeong-Chuan Kao ${ }^{\mathrm{b}}$ \\ a Department of Mechanical Engineering, National Taiwan University, Taipei 106, Taiwan \\ ${ }^{\mathrm{b}}$ Department of Physics, National Taiwan University, Taipei 106, Taiwan
}

\section{H I G H L I G H T S}

- A spiral multiple-effect diffusion solar still is developed.

- The measured water productivity is higher than the published results.

- The manufacture of spiral solar is easier and cheaper.

\section{A R T I C L E I N F O}

\section{Article history:}

Received 22 December 2014

Received in revised form 2 February 2015

Accepted 4 February 2015

Available online $\mathrm{xxxx}$

\section{Keywords:}

Solar desalination

Solar distillation

Solar still

Multiple-effect diffusion solar still

\begin{abstract}
A B S T R A C T
A novel solar still with spiral-shape multiple-effect diffusion unit is developed in the present study. The test results of a 14-effect unit coupled with vacuum-tube solar collector (absorber area $1.08 \mathrm{~m}^{2}$ ) show that the highest daily pure water production is $40.6 \mathrm{~kg} \mathrm{~d}^{-1}$. The measured highest productivity based on the area of glass cover, solar absorber, and evaporating surface is $34.7,40.6$, and $7.96 \mathrm{~kg} \mathrm{~m}^{-2} \mathrm{~d}^{-1}$, respectively, which are much higher than the published results. The measured solar distillation efficiency is 2.0-3.5. The performance enhancement results mainly from the lateral diffusion process in the spiraled still cell. The vapor flow generated by heat input can flow freely and laterally through the spiral channel down to the end when solar heat input is high. Besides, the larger evaporating and condensing area at the outer cell may increase heat and mass transfer at the outer cell.
\end{abstract}

(ㄷ) 2015 Elsevier B.V. All rights reserved.

\section{Introduction}

Many researches have proved that multiple-effect diffusion solar still (MEDS) has high productivity [1-14]. MEDS consists of a multiple-effect diffusion unit (MDU), a solar collector, a heat recovery exchanger, and a heat transfer device to connect solar collector and MDU. The conventional MDU (Fig. 1) is made of a number of closely packed vertical still cells. Each cell is made of a heating plate and a thin wick (porous) material which is attached on one side of the heating plate. The seawater or sewage water is supplied to the wick from the top. The heating plate absorbs heat from vapor condensation (latent heat) and conducts the heat through the plate to the liquid-saturated wick at the other side to evaporate the water. The vapor diffuses and condenses on the heating plate of the next cell. The processes repeat until the last cell and finally discharge the heat to the ambient. The water collector under the heating plates collects the pure water. The effluent from sewage water is collected in

\footnotetext{
* Corresponding author.

E-mail address: bjhuang@seed.net.tw (B.-J. Huang).
}

another collector. Heat is applied to the heating plate in the first cell. The heat source of MEDS is from the solar collector.

The configuration of MEDS may be different. Dunkle [4] built a solar distillation system consisting of a MDU and a storage tank which is connected to a solar collector. Cooper and Appleyard [5] simplified Dunkle's design by combining the solar collector and the MDU into one such that the first plate of MDU acts as the solar absorber. It was found that the productivity is significantly improved by narrowing the diffusion gaps between the parallel plates [7-10].

Tanaka et al. [11] further designed a basin-type MEDS consisting of a MDU coupled with a basin-type distillation section, called "MEDSBasin". The measured productivity was the highest in literature in the 2000's. Tanaka et al. [15-17] showed theoretically that the productivity of MEDS can be higher.

Chong et al. [18,19] designed a similar MEDS of Tanaka et al. [15-17] but using a bended-plate MDU coupled with a vacuum-tube solar collector. The bended-plate MDU solves the problem of wick peel-off from the heating plate and pure water contamination. The vacuumtube solar collector creates a higher temperature gradient in MDU to increase the productivity. The outdoor test of a MEDS prototype (MEDS- 


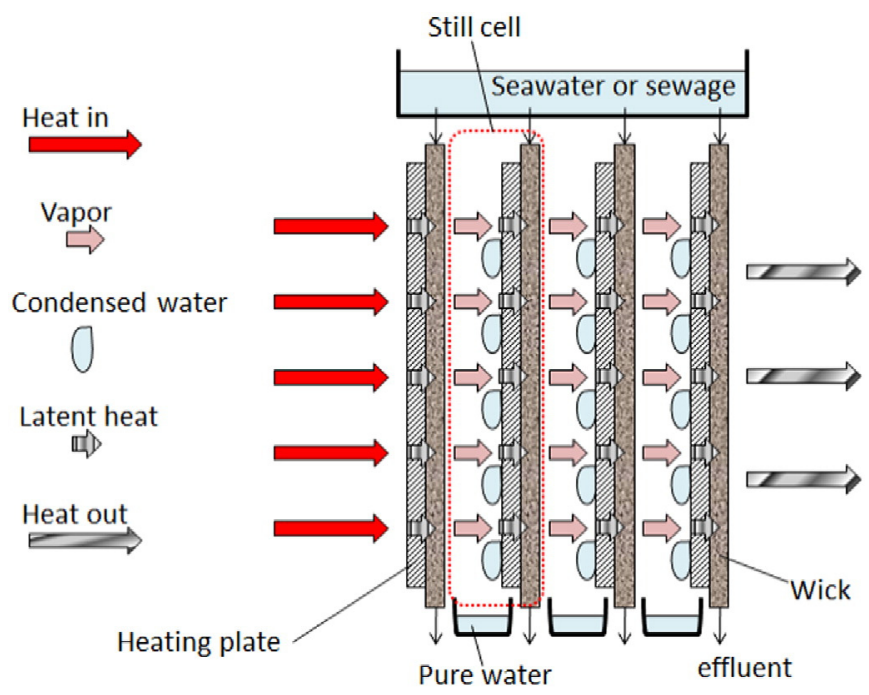

Fig. 1. Distillation process inside multiple-effect diffusion unit (MDU) [18].

1L) [18] shows that the productivity is much higher than the test results of MEDS-Basin [11] and the theoretical calculation of MEDS-FHP [17].

The long-term outdoor test results of MEDS-1L show that the average daily pure water production is higher than the basin-type MEDS $[11,18]$. The solar distillation efficiency $R_{\text {cov }}(\mathrm{COP})$ is $23 \%$ higher than the basin-type MEDS [11].

The bended-plate MDU of Chong et al. $[18,19]$ is designed in a laminated-structure in which the bended plates/wicks are laminated piece by piece with a silicone rubber spacer in between to seal each diffusion gap. The heat path is in outward direction perpendicular to the plate. The diffusion gaps are sealed in each still cell. Hence, the resistance of heat transfer and diffusion process becomes higher if the number of multiple-effect cells is high. Besides, the manufacturing process for laminated-structure and bended-plate of MDU is not very simple because the plate and wick are in piecewise form and need a bonding process to make a good sealing at the edge.

The present study further develops a MEDS with a novel design of MDU in which the plate/wick and the diffusion gap are in spiral shape. The plate and the wick are in one single sheet. A continuous manufacturing process is employed by rolling the plate/wick sheet with seal/spacer placed at two edges.

In the spiral design, the still cell gap is a single spiraled continuous cell from the first heating section (from solar heat) to the last heat sink section (to ambient). Beside the vapor diffusion in the direction perpendicular to the plate, vapor can also flow freely and laterally down to the end of the still cell to enhance the mass transfer. This may create a better thermal and mass transfer process at high heat input (high solar radiation). In addition, the MDU is coupled with a vacuum-tube solar collector which can produce a higher temperature gradient in MDU for high productivity. A thermosyphon heat pipe is used to connect the MDU and solar collector to effectively transfer the solar heat to the MDU.

\section{Design of multiple-effect diffusion solar still with spiral cell (MEDS-sp)}

Fig. 2 shows the schematic diagram of multiple-effect diffusion solar still (MEDS-sp). It consists of a spiral-type multiple-diffusion unit (sMDU) which is heated by solar heat from a vacuum-tube solar collector via a heat pipe (thermosyphon). A heat recovery exchanger is used to recover the heat of hot brine and distilled water to preheat the feed water.

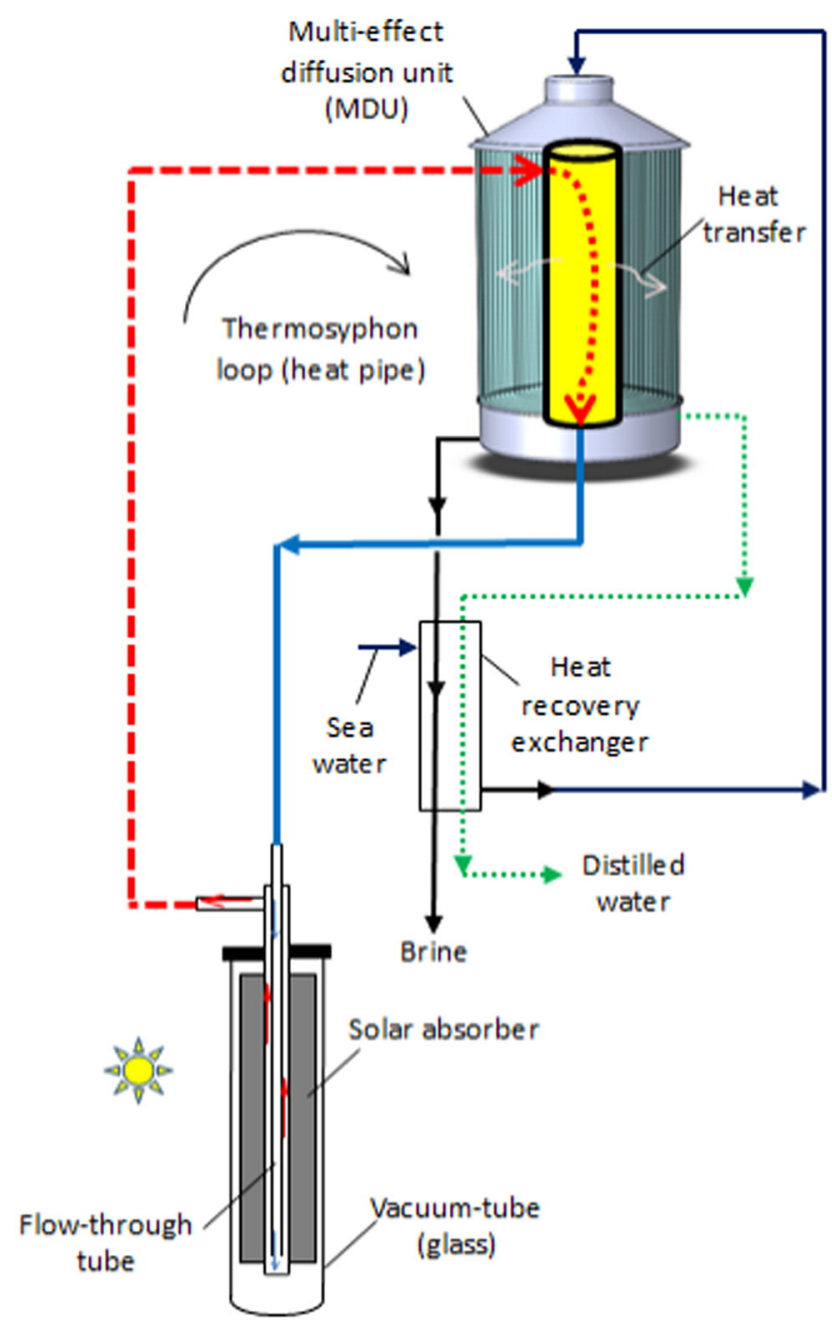

Fig. 2. Schematic diagram of MEDS-sp.

\subsection{Design of spiral-shape multiple-effect diffusion unit (sMDU)}

The design concept of spiral-shape MDU is shown in Fig. 3. The heating plate (polycarbonate) and the wick are spiraled together with seal/spacer placed at two edges. During the process of rolling the plate, the wick material is stretched on the curved heating plate to create a tensile force for tight contact with the plate. Wick peel-off problem can then be solved.

Two silicone rubber spacer/seals at the top and bottom edges were used. The top spacer/seal is in a rectangular shape in cross section. The bottom spacer/seal (called "ditch component" in Fig. 3(a)) also acts as a ditch for pure water collection. Both spacer/seals are made from extrusion of silicone rubber. Silicone rubber pipes for feed water flow are placed inside the ditch to recover the heat of pure water and inside the brine collector to recover the heat of brine.

In the spiral MDU, there is only one still cell which is in spiral shape. Besides the vapor diffusion across the gap in the outward direction perpendicular to the plate (radial diffusion), lateral diffusion along the circumference down to the end of the spiral cell may occur, see Fig. 3(b). The lateral diffusion may induce an additional mass transfer effect which increases vaporization of water in the wick and condensation of vapor on the bare side of heating plate.

Fig. 4 shows the schematic diagram of the design of spiral multipleeffect diffusion unit (sMDU). The feed water first flows down and is heated in the heat recovery pipes of pure water and brine at the bottom and then flows up and is fed to a pulp sponge (at the top) which 


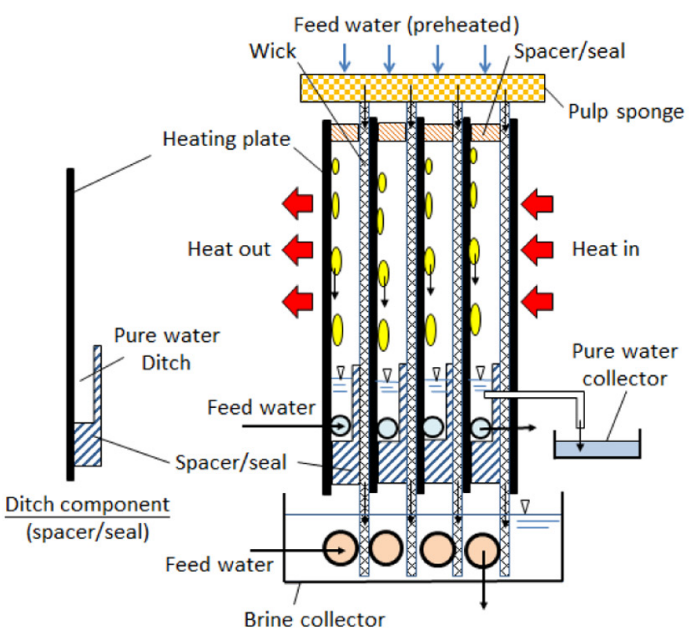

(a)

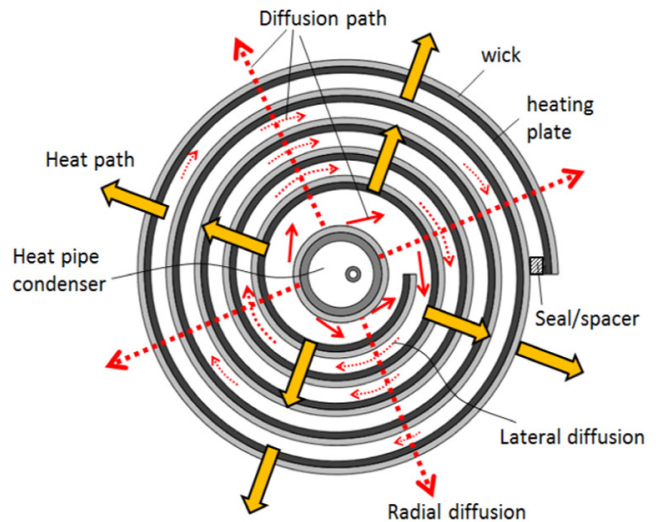

(b)

Fig. 3. Design concept of spiral MDU (cross-sectional view).

distributes the flow evenly into the wick. The wick flow is from the pulp sponge at the top all the way down to the brine collector through the heating plate where distillation process takes place. The pure water condensate on the bare side of heating plate flows down and is collected at the ditch. The flow of pure water and brine is thus separated quite well by this design. Fig. 5(a) is the prototype of sMDU without wick showing how the spacer/seals are used to create a uniform cell gap and sealing effect. Fig. 5(b) shows the final prototype of sMDU.

The design of the condenser section of heat pipe inside sMDU is much simple as compared to that of MEDS-1L [18]. As shown in Fig. 6, the condenser is made of a copper pipe. Vapor from solar collector flows into the condenser through the vapor tube. The condensate of vapor then flows down and back to the solar collector. A wick material is tightly attached on the outside heating surface of the condenser by a pre-stretching process of wick to absorb solar heat and generates the first vapor for successive distillation process. In mass production, sintered material can be used and a porous layer can be attached on the heating surface. The design specification of sMDU is shown in Table 1.

The wick of sMDU is in contact with the heating plate due to the curved spiral structure. However, the dissolved gas in water such as oxygen may be evolved and produce bubbles which may cause wick peel-off problem. The water flow rate through the wick needs to be controlled to avoid wick dry-out and bubble formation. Similar to MEDS-1L [18], a test of the wick material used in the present study shows that, the bubble problem at $100{ }^{\circ} \mathrm{C}$ can be avoided if the ratio of pure water flow to brine or effluent flow is in the range $0.3-2.0$ or the ratio of inlet water flow to pure water flow is in the range 1.3-3.0.

\subsection{Vacuum-tube solar collector and thermosyphon (heat pipe)}

A flow-through vacuum-tube solar collector module (EZL 100-6) made by Viessmann Heating Technology Beijing Co., Ltd. used in MEDS1L [18] was used in the present MEDS-sp. EZL 100-6 has 6 tubes with a

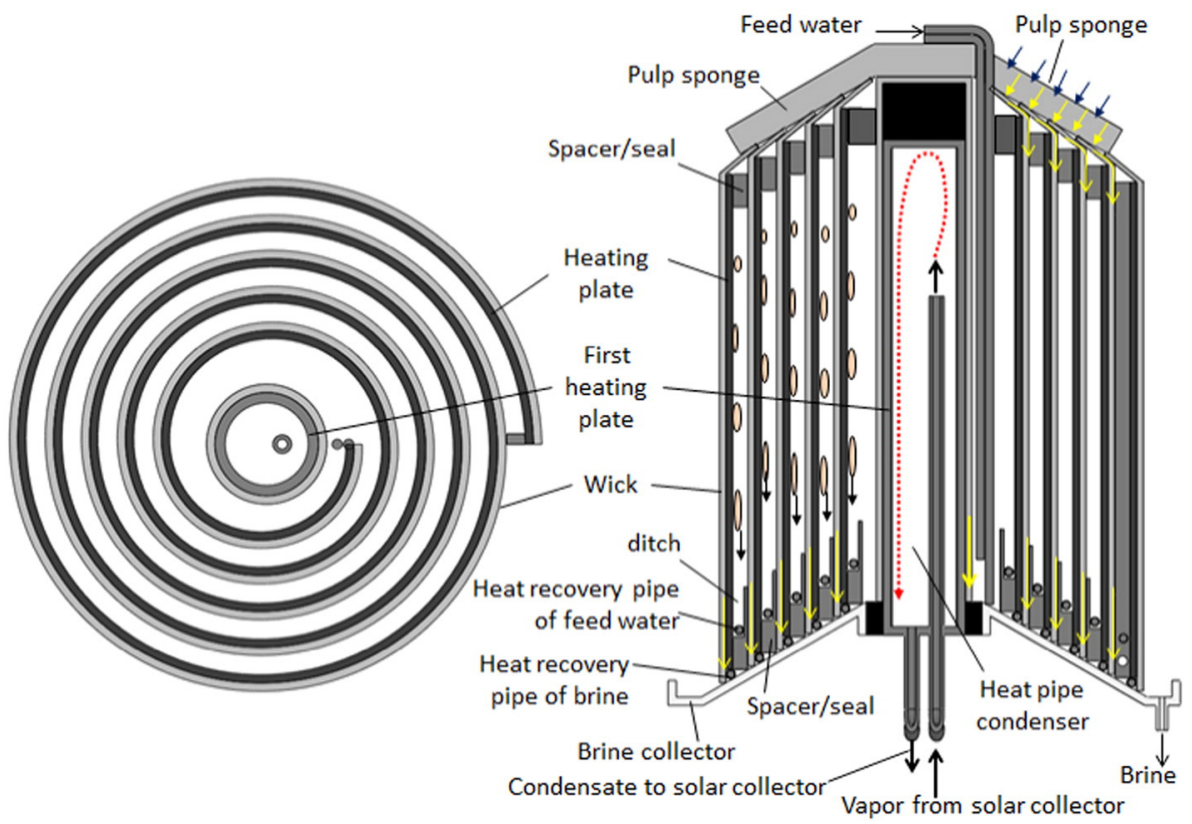

Fig. 4. Schematic diagram of sMDU prototype design. (a) Without wick. (b) With wick. 


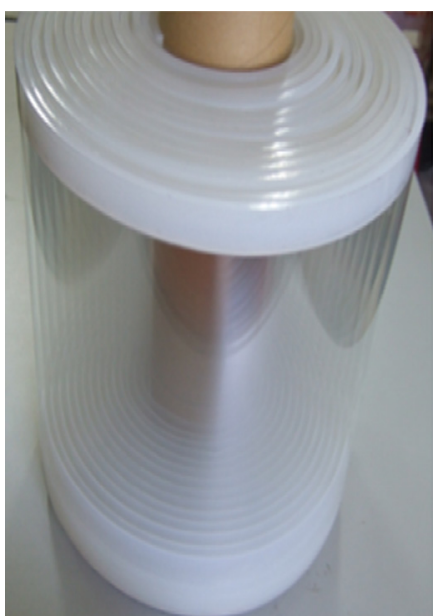

(a) without wick

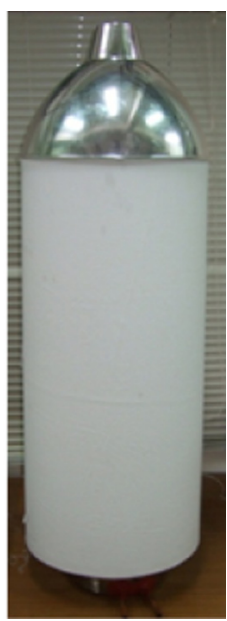

(b) with wick
Fig. 5. Manufacture of sMDU.

total absorber area of $1.08 \mathrm{~m}^{2}$. The measured solar collector efficiency is around $0.6-0.7$ operated at steam generation mode $\left(100{ }^{\circ} \mathrm{C}\right)$.

The high-quality vacuum-tube solar collector is shown to be able to provide heating temperature up to $100{ }^{\circ} \mathrm{C}$ to sMDU to create high temperature gradient to improve MEDS performance.

The solar energy collected by the vacuum-tube collector is delivered to sMDU through a thermosyphon loop (heat pipe). The solar energy absorbed by the metallic absorber (fin) is conducted to the working fluid of heat pipe inside the flow-through tube and causes evaporation. The vapor flows to sMDU through the connecting pipe and enters the condenser through vapor tube (Fig. 2).

Condensation heat of the working fluid is released to the wick attached outside the heating surface of the condenser and makes the first vapor for successive distillation process. The condensate of heat pipe flows back to the evaporator (solar collector) by gravitational force. This completes a heat transport cycle. The working fluid used in the present study is pure water which is charged to the heat pipe after evacuation, about 21.

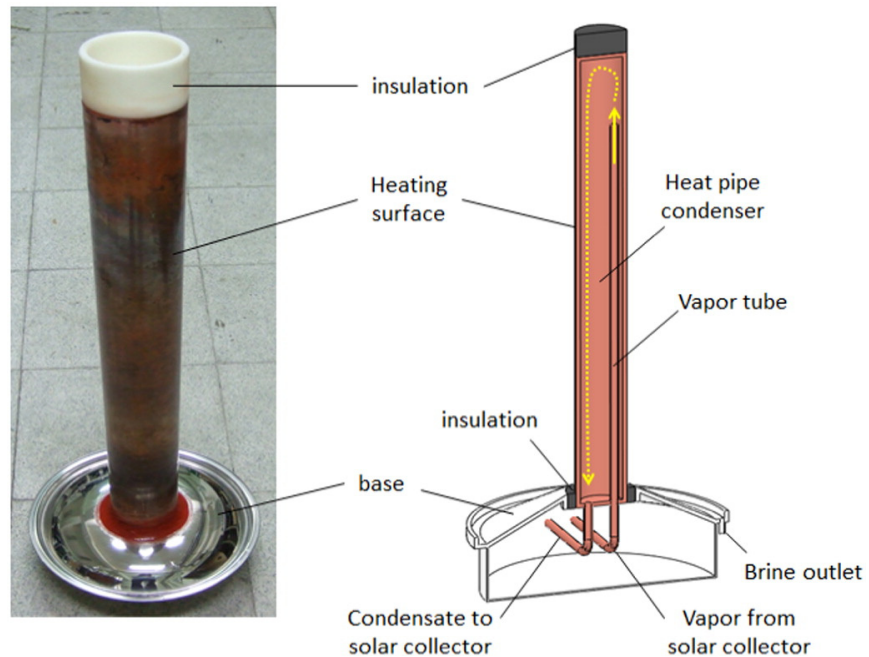

Fig. 6. Condenser section of heat pipe in sMDU.
Table 1

Design specifications of sMDU.

\begin{tabular}{|c|c|}
\hline Shape & Spiral \\
\hline Cell dimension & H $0.7 \mathrm{~m} \times$ L $8.3 \mathrm{~m}$ (spiraled shape), gap $7 \mathrm{~mm}$; \\
\hline \multirow[t]{3}{*}{ Cell material } & Plate: polycarbonate (PC), thickness $0.254 \mathrm{~mm}$ \\
\hline & $\begin{array}{l}\text { Wick: nonwoven } 100 \% \text { wooden fiber (used in coffee maker), } \\
\text { thickness } 0.225 \mathrm{~mm}\left(69 \mathrm{~g} / \mathrm{m}^{2}\right)\end{array}$ \\
\hline & Spacer: silicone rubber \\
\hline $\begin{array}{l}\text { No. of multiple } \\
\text { effects }\end{array}$ & 14 \\
\hline $\begin{array}{l}\text { Total evaporating } \\
\text { surface area }\end{array}$ & $0.62 \mathrm{~m} \times 8.25 \mathrm{~m}=5.1 \mathrm{~m}^{2}$ \\
\hline \multirow{5}{*}{$\begin{array}{l}\text { Condenser of heat } \\
\text { pipe }\end{array}$} & Cylindrical tube: cooper, dia. $80 \mathrm{~mm}(2 \mathrm{t})$, height $700 \mathrm{~mm}$ \\
\hline & Effective heating area: $\mathrm{H} 680 \mathrm{~mm}, 80 \mathrm{~mm}$ dia. \\
\hline & Vapor tube: dia. $10 \mathrm{~mm}(1 \mathrm{t})$, copper tube \\
\hline & Wick on outside heating surface: nonwoven $100 \%$ wooden \\
\hline & $\begin{array}{l}\text { fiber (used in coffee maker), thickness } 0.225 \mathrm{~mm}\left(69 \mathrm{~g} / \mathrm{m}^{2}\right) \text {, } \\
3 \text { layers }\end{array}$ \\
\hline \multirow[t]{4}{*}{ Heat recovery pipes } & Length: $8.25 \mathrm{~m}$ each for pure water and brine \\
\hline & Inside diameter: $4 \mathrm{~mm}$ \\
\hline & Thickness: $0.5 \mathrm{~mm}$ \\
\hline & Material: silicone rubber \\
\hline
\end{tabular}

\subsection{Experimental setup}

Fig. 7 shows the prototype of MEDS-sp. The vacuum-tube solar collector and sMDU are connected by heat pipe.

MEDS-sp was tested at the outdoor. The same automatic measuring system of MEDS-1L [18] is used for long-term experiment (Fig. 8). A weight measuring device was designed using weighing method. The pure water and the brine water were drained from SMDU into two tanks separately and the weight was measured by digital scales (BHW-30 by Shinko Co.) with uncertainty of $\pm 3 \%$. A solenoid valve was installed at the bottom of each tank to empty the water at night. The instantaneous and accumulated water outflow can be measured automatically. Temperatures at solar collector exit $\left(T_{h}\right)$, condenser heating surface of sMDU $\left(T_{p 1}\right)$ (Fig. 8), and ambient $\left(T_{a}\right)$ were measured using thermocouples (with uncertainty of $\pm 0.8^{\circ} \mathrm{C}$ ). Solar radiation was measured using a pyrometer LP PYRA 03 (by Delta OHM Co.) with uncertainty of $\pm 5 \%$. The whole measurement is automatic and all the data are recorded by a recorder MV100 (by YOKOGAWA). The sampling time interval is $1 \mathrm{~min}$.

The feeding rate of MEDS-sp was regulated manually by a valve and set at $120-130 \mathrm{~g} / \mathrm{min}$, about twice of the maximum production rate of the still, to avoid bubble formation and peer-off of wick material as described in Section 2.1. That is, the flow ratio of inlet water to pure water is in the range of 1.3-3.0. No electric power is needed for feeding water in the experiment.

\section{Test results}

\subsection{Daily performance of MEDS-sp under different weather conditions}

The tap water from a reservoir on the rooftop of building was used as the inlet water in the experiment. Fig. 9 shows the test result of MEDSsp in sunny weather $(2013 / 5 / 06)$. It is seen that both of the solar collector supply temperature $T_{h}$ and the heating plate temperature $T_{p 1}$ keeps $100{ }^{\circ} \mathrm{C}$ at solar radiation $I_{T}=600-750 \mathrm{~W} \mathrm{~m}^{-2} . T_{h}$ and $T_{p 1}$ reach $70-90{ }^{\circ} \mathrm{C}$ and $53-88^{\circ} \mathrm{C}$, respectively, at $I_{T}=400 \mathrm{~W} \mathrm{~m}^{-2}$, depending on the cold/ hot status of sMDU due to thermal mass effect. The daily-total pure water production $\left(D_{w}\right)$ is $39.9 \mathrm{~kg} \mathrm{~d}^{-1}$.

The test result of MEDS-sp in partly-cloudy weather (2013/5/25) is shown in Fig. 10. Both $T_{h}$ and $T_{p 1}$ in sMDU reach $100{ }^{\circ} \mathrm{C}$ most of the time. The daily-total pure water production $\left(D_{w}\right)$ is $31.2 \mathrm{~kg} \mathrm{~d}^{-1}$. 

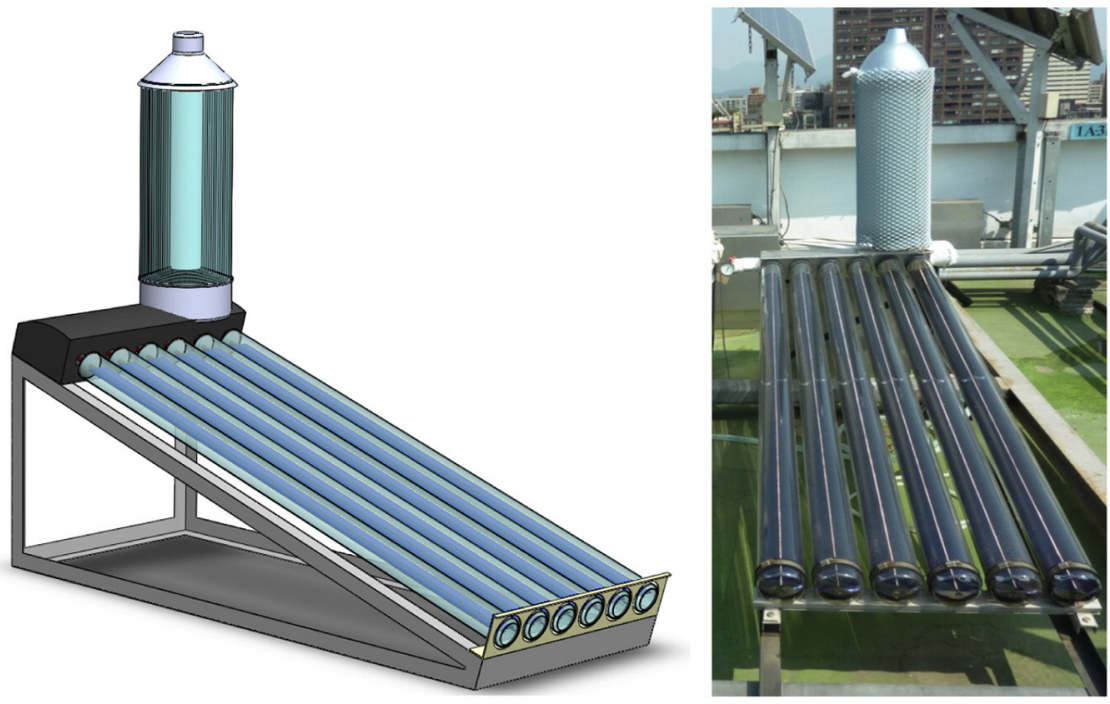

Fig. 7. Prototype of MEDS-sp.

\subsection{Long-term performance comparison of MEDS-sp}

The long-term performance data of MEDS-sp is calculated based on four performance indexes proposed by Chong et al. [18] for comparison.

(1) Daily pure water production per unit area of glass cover $M_{c o v}$

$$
M_{c o v}=D_{W} / A_{c o v}
$$

where $D_{w}$ is the daily pure water production; and $A_{\text {cov }}$ is the area of glass cover. For vacuum-tube collector, it is calculated based on the outside diameter of the glass tube.

(2) Daily pure water production per unit area of solar absorber, $M_{\text {sol }}$

$$
M_{\text {sol }}=D_{W} / A_{\text {sol }}
$$

where $A_{\text {sol }}$ is the area of the solar absorber.

(3) Daily pure water production per unit area of evaporating surface $M_{\text {evp }}$

$$
M_{e v p}=D_{W} / A_{e v p}
$$

where $A_{\text {evp }}$ is the total area of evaporating surface.

(4) Daily solar distillation efficiency of MEDS based on incident solar energy on glass cover $R_{\text {cov }}$ :

$$
R_{\text {cov }}=h_{f g} D_{W} /\left(H_{T} A_{c o v}\right)=h_{f g} M_{c o v} / H_{T}
$$

where $h_{f g}$ is the latent heat of water; and $H_{T}$ is daily-total solar radiation incident upon glass cover of MEDS. $R_{\text {cov }}$ is the ratio of total energy required to produce the pure water to the total solar incident energy. It is also called "the coefficient of performance (COP) of MEDS". $M_{c o v}, M_{s o l}, M_{\text {evp }}$ and $R_{\text {cov }}$ are used to evaluate the performance of MEDS-sp and compare with other published results.

The measured daily pure water production $D_{w}$ is converted into $M_{c o v}$, $M_{\text {sol }}, M_{\text {evp }}$ and $R_{\text {cov }}$ to compare with the published data [11,15-18].

\subsubsection{Comparison of $M_{\text {cov }}$}

Fig. 11 shows that the measured highest $M_{\text {cov }}$ of MEDS-sp is $34.7 \mathrm{~kg} \mathrm{~m}^{-2} \mathrm{~d}^{-1}$ at $H_{T}=24.9 \mathrm{MJ} \mathrm{m}^{-2} \mathrm{~d}^{-1}$ which is about $86 \%$ higher than the highest test result of MEDS-Basin [11] $\left(18.7 \mathrm{~kg} \mathrm{~m}^{-2} \mathrm{~d}^{-1}\right.$ at $H_{T}=22.4 \mathrm{MJ} \mathrm{m}^{-2} \mathrm{~d}^{-1}$ ) with 11-effect MDU.

If the averaged data (linear regression lines) were used to compare the performance, $M_{\text {cov }}$ is $93 \%$ higher than that of MEDS-Basin [11] at $H_{T}=15.2 \mathrm{MJ} \mathrm{m}^{-2} \mathrm{~d}^{-1}$ and $66 \%$ higher at $H_{T}=22.4 \mathrm{MJ} \mathrm{m}^{-2} \mathrm{~d}^{-1} \cdot M_{c o v}$ is 75\% higher than that of MEDS-Basin [11]. $M_{\text {cov }}$ is higher than the calculation of MEDS-FHP [17] by $85 \%-89 \%$ as shown in Table 2.

Table 3 and Fig. 11 show that $M_{\text {cov }}$ of MEDS-sp is higher than that of MEDS-1L [18] by about 47\%. The performance improvement due to the high temperature gradient of MDU created by the vacuum-tube solar collector has been experimentally verified in MEDS-1L [18]. Further performance enhancement of MEDS-sp over MEDS-1L [18] is due to the enhanced diffusion process in the spiraled still cell. Lateral diffusion may take place and enhance the diffusion flow as well as the water evaporation and vapor condensation processes inside the spiraled cell, as shown in Fig. 3(b).
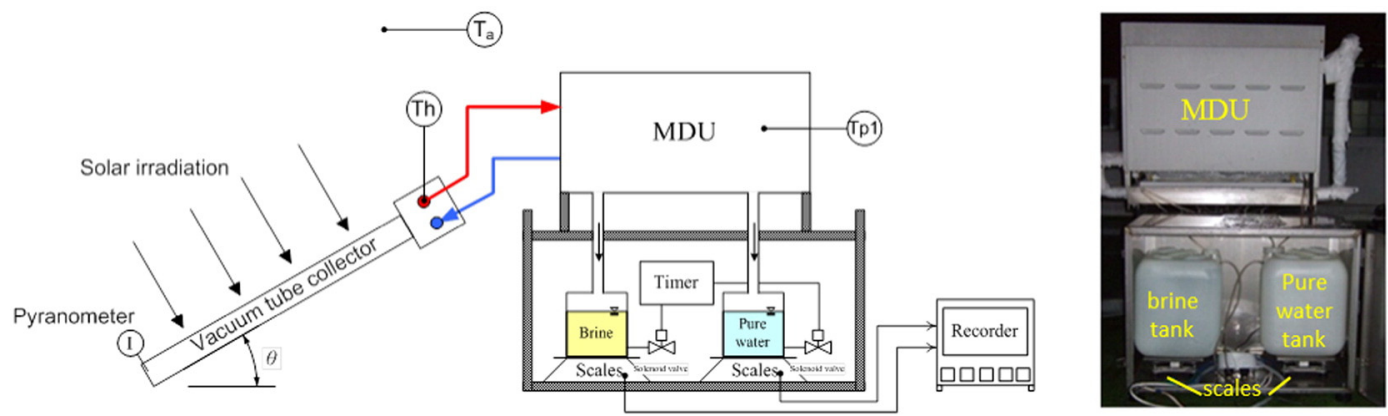

Fig. 8. Automatic measuring system for long-term performance of MEDS-sp [18]. 


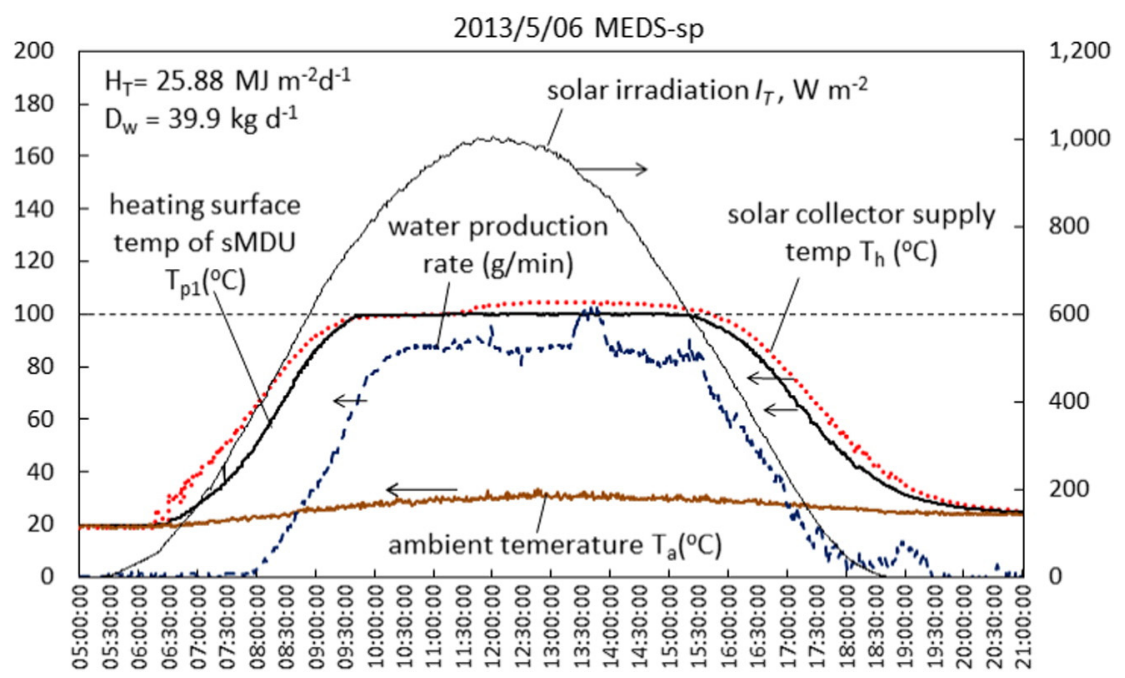

Fig. 9. Test result of MEDS-sp in sunny day (2013/5/06).

\subsubsection{Comparison of $M_{\text {sol }}$}

Fig. 12 shows that $M_{\text {sol }}$ of MEDS-sp is much higher than that of MEDS-Basin [11]. The highest $M_{\text {sol }}$ is $40.6 \mathrm{~kg} \mathrm{~m}^{-2} \mathrm{~d}^{-1}$ at $H_{T}=$ $24.9 \mathrm{MJ} \mathrm{m}{ }^{-2} \mathrm{~d}^{-1}$, which is about $217 \%$ higher than MEDS-Basin [11] $\left(12.8 \mathrm{~kg} \mathrm{~m}^{-2} \mathrm{~d}^{-1}\right.$ at $\left.H_{T}=22.4 \mathrm{MJ} \mathrm{m}^{-2} \mathrm{~d}^{-1}\right)$. The total solar absorber area of MEDS-Basin is $2.25 \mathrm{~m}^{2}$, while the total solar absorber area of MEDS-sp is only $1.08 \mathrm{~m}^{2}$. In overall average (linear regression lines), $M_{\text {sol }}$ of MEDS-sp is $200 \%$ higher than that of MEDS-Basin [11], as can be seen from Table 3.

It can be seen from Table 3 that the measured $M_{\text {sol }}$ of MEDS-sp is much higher than the calculation of MEDS-FHP [17] by $116 \%-121 \%$. Table 3 and Fig. 12 also show that the measured $M_{\text {sol }}$ of MEDS-sp is higher than that of MEDS-1L [18] by $59 \%$.

\subsubsection{Comparison of $M_{\text {evp }}$}

Fig. 13 shows that the highest $M_{\text {evp }}$ of MEDS-sp is $7.96 \mathrm{~kg} \mathrm{~m}^{-2} \mathrm{~d}^{-1}$ at $H_{T}=24.9 \mathrm{MJ} \mathrm{m} \mathrm{m}^{-2} \mathrm{~d}^{-1}$, about four times of MEDS-Basin [11] ( $2.02 \mathrm{~kg} \mathrm{~m}^{-2} \mathrm{~d}^{-1}$ at $H_{T}=22.4 \mathrm{MJ} \mathrm{m}^{-2} \mathrm{~d}^{-1}$ ) which has a total evaporating surface area of $14.25 \mathrm{~m}^{2}$ in the 11-effect MDU. The total evaporating surface of MEDS-sp is only $5.1 \mathrm{~m}^{2}$, about one third. This indicates that MEDS-sp is more efficient in the multiple-diffusion and evaporating process inside the still cell. In overall, $M_{\text {evp }}$ of MEDS-sp is $272 \%$ higher than that of MEDS-Basin [11], as can be seen from Table 3. Table 3 also shows that the measured $M_{\text {evp }}$ of MEDS-sp is higher than MEDS-FHP [17] by 366\%-376\%.

Table 3 and Fig. 13 also show that the measured $M_{\text {evp }}$ of MEDS-sp is much higher than that of MEDS-1L [18] by $188 \%$.

3.2.4. Solar distillation efficiency (coefficient of performance COP) $R_{\text {cov }}$

The energy efficiency of a MEDS can be represented by solar distillation efficiency $R_{\text {cov }}$ which is "the coefficient of performance (COP) of MEDS" defined in Eq. (4). Fig. 16 shows that the highest $R_{\text {cov }}$ of MEDSsp is 3.49 at $H_{T}=20.5 \mathrm{MJ} \mathrm{m}^{-2} \mathrm{~d}^{-1}$, about $85 \%$ higher than the test result of MEDS-Basin [11] (1.88 at $\left.H_{T}=22.4 \mathrm{MJ} \mathrm{m}^{-2} \mathrm{~d}^{-1}\right) \cdot R_{\text {cov }}$ of MEDS-sp is in the range of 2.0-3.5, while the MEDS of MEDS-Basin [11] is 1.45-1.88. In overall, $R_{\text {cov }}$ of MEDS-sp is 78\% higher than that of MEDS-Basin [11], as can be seen from Table 2 .

Table 2 shows that the measured $R_{\text {cov }}$ of MEDS-sp is higher than the calculation of MEDS-FHP [17] by 109\%-125\%. Although the area of solar absorber and evaporating surface used in MEDS-sp are about half and one quarter of MEDS-FHP, respectively, the solar distillation efficiency $R_{\text {cov }}$ of MEDS-sp is doubled.

Table 3 and Fig. 14 also show that the measured $R_{\text {cov }}$ of MEDS-sp is higher than that of MEDS-1L [18] by 44\%. This resulted from the enhanced diffusion process in the spiraled still cell due to lateral diffusion. In Fig. $14, R_{\text {cov }}$ of MEDS-sp tends to approach a saturated value at high

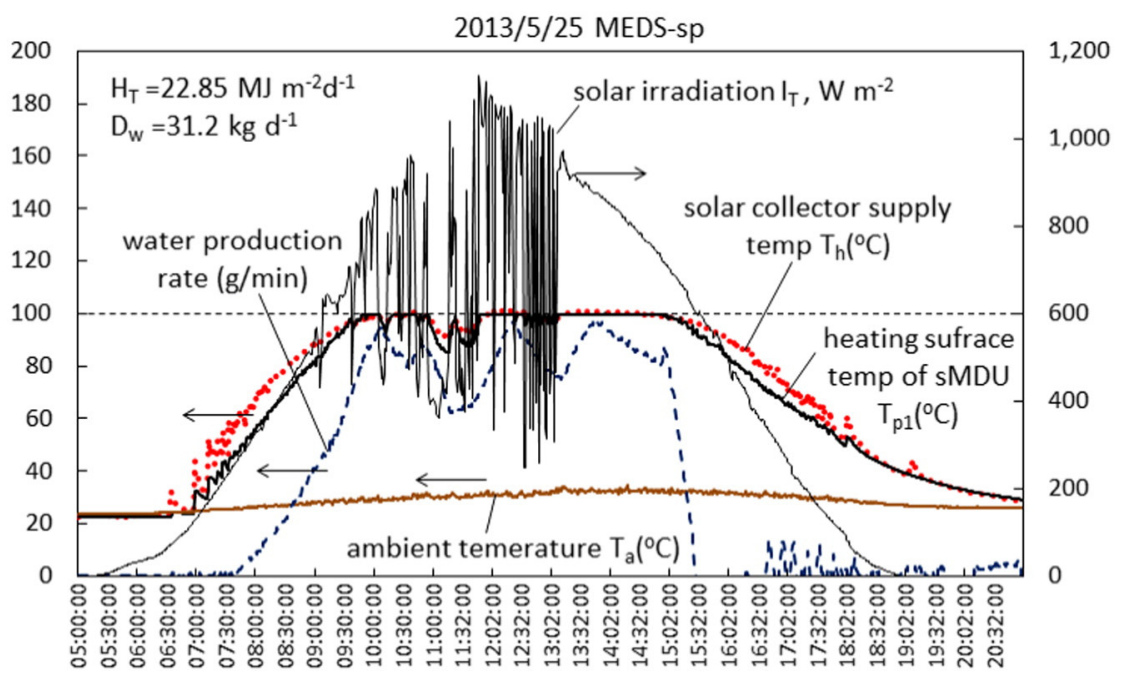

Fig. 10. Test result of MEDS-sp in partly-cloudy weather (2013/5/25). 


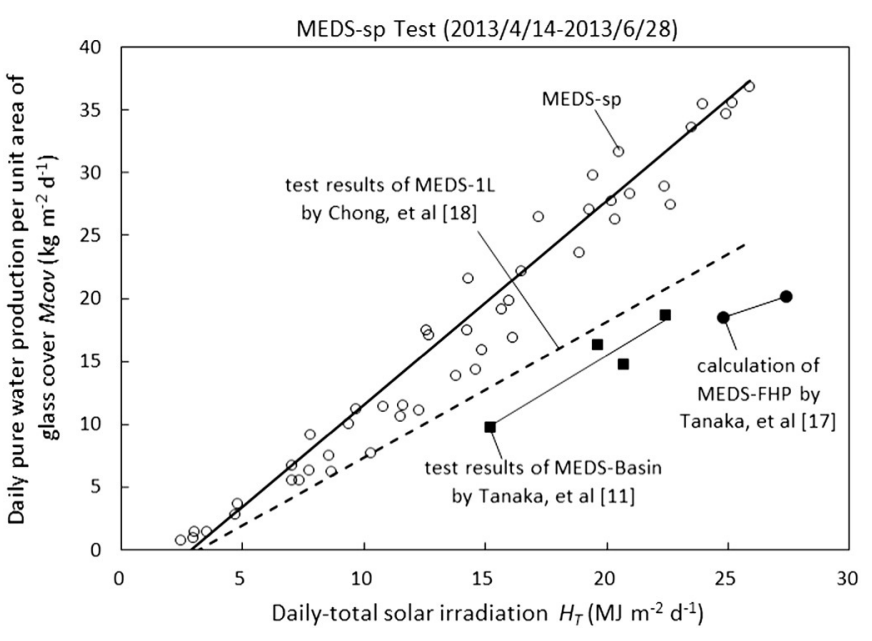

Fig. 11. Comparison of water productivity per unit area of glass cover.

$H_{T}$. Fig. 11 shows that $M_{c o v}$ is proportional to $H_{T}$ which can be expressed in a linear form:

$M_{c o v}=a+b H_{T}$

where $a=-4.66$ and $b=1.62$ from linear regression of data in Fig. 11 . From the definition of $R_{c o v}$, Eq. (4), we obtain

$R_{\text {cov }}=h_{f g} M_{c o v} / H_{T}=h_{f g}\left(a+b H_{T}\right) / H_{T}=h_{f g}\left(-4.66 / H_{T}+1.62\right)$.

Therefore, the $R_{\text {cov }}$ correlation of MEDS-sp coincides with Eq. (6) as shown in Fig. 14. This may result from the fact that, the lateral vapor flow has been down to the end of still cell with very high heat input. Hence, no more water production can be obtained even if heat input is increased.
According to Eq. (4), the measurement uncertainty of $R_{\text {cov }}$ and $w_{R}$, can be calculated from Eq. (7) [21]:

$w_{R}=\sqrt{w_{D w}^{2}+w_{H_{T}}^{2}}=5.8 \%$.

where $w_{D w}$ is the relative measurement uncertainty of daily pure water production $D_{w}(3 \%)$; and $w_{H T}$ is the relative measurement uncertainty of daily total solar irradiation $H_{T}(5 \%)$.

\section{Discussion}

The performance improvement of MEDS-1L [18] over MEDS-Basin [11] and MEDS-FHP [17] is mainly due to the high temperature gradient of MDU created by vacuum-tube solar collector.

In the present study, sMDU has a single cell in spiraled shape. The measured $M_{c o v}, M_{\text {sol }}, M_{\text {evp }}$, and $R_{\text {cov }}$ of MEDS-sp are much higher than MEDS-1L [18]. The performance enhancement in MEDS-sp results mainly from the enhanced diffusion process inside the spiraled still cell. Lateral diffusion flow may take place and enhance water evaporation and condensation processes. This occurs especially at high solar radiation.

An experiment was carried out by Huang et al. [19] for a bendedplate MDU, with a wick dimension of $30 \mathrm{~cm} \times 40 \mathrm{~cm}$, using steam as the input. It was found that the measured COP of MDU, $R_{0}$, as defined in Eq. (8), decreases with increasing heat flux through the still cell $q_{h}$, as shown in Fig. 15 which is converted from the data of Table 5 of [19].

$R_{o}=\frac{\text { latent heart required for total pure water production }}{\text { heat input to MDU }}$

High heat flux $q_{h}$ through the still cell creates higher resistance in heat and mass transfer process in a closed-type still cell, since the vapor generation and condensation flow may be limited by limited surface area of wick/plate at high heat input. For open-type spiral still cell of sMDU, the vapor flow generated by heat input can flow freely and laterally through the spiral channel down to the end when heat input is high. This will create a lower average heat flux to the wick/plate surface in

Table 2

Performance comparison of MEDS-sp with MEDS-Basin [11] and MEDS-FHP [17]

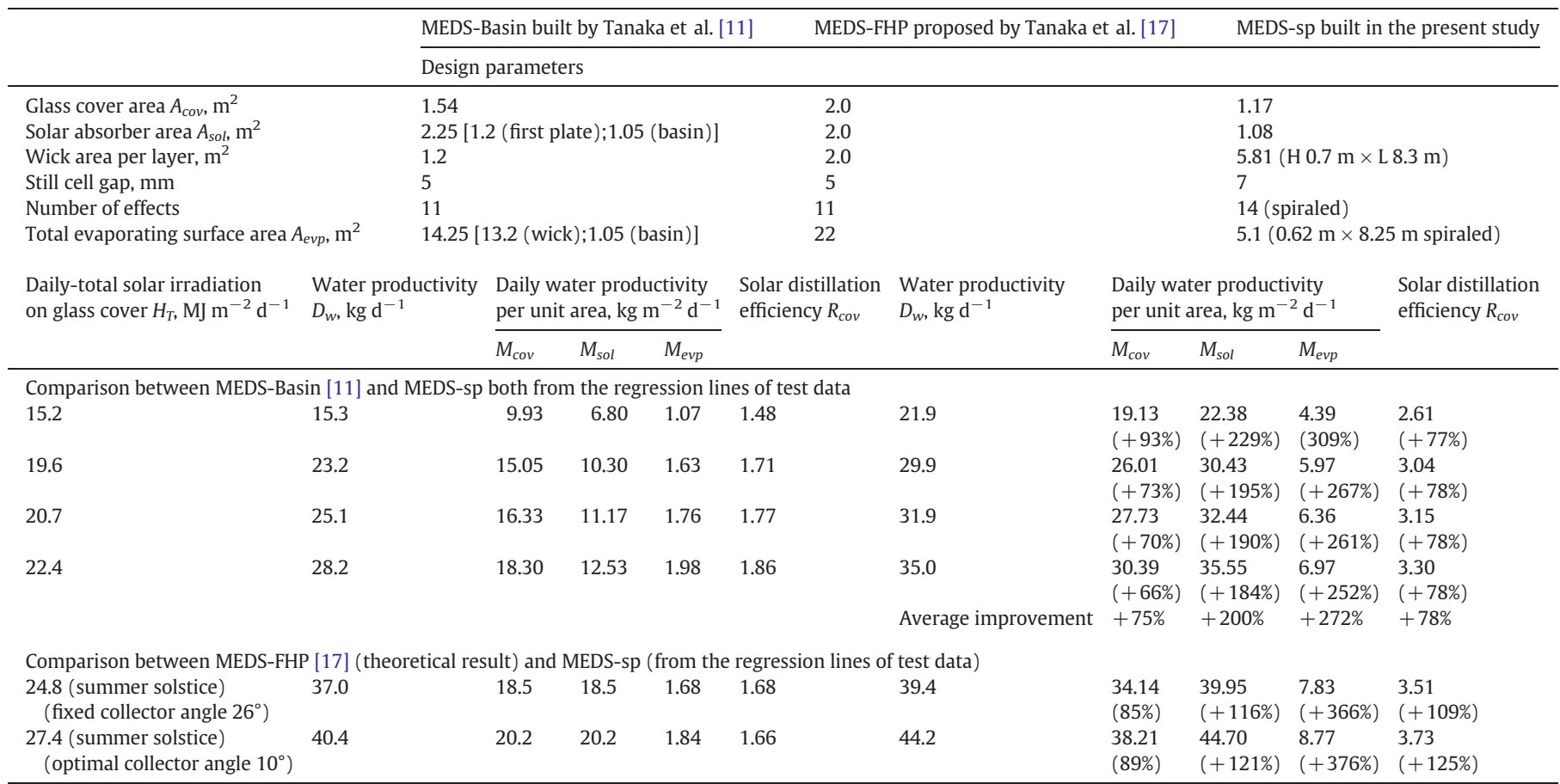


Table 3

Performance comparison of MEDS-sp with MEDS-1L [18].

\begin{tabular}{|c|c|c|c|c|c|c|c|c|c|c|}
\hline & & & & & \multicolumn{4}{|c|}{$\begin{array}{l}\text { MEDS-1L } \\
\text { built by Chong et al. [18] }\end{array}$} & \multicolumn{2}{|c|}{$\begin{array}{l}\text { MEDS-sp } \\
\text { built in the present study }\end{array}$} \\
\hline & & & & & \multicolumn{6}{|l|}{ Design parameters } \\
\hline \multicolumn{5}{|l|}{ Glass cover area $A_{\text {cov }}, \mathrm{m}^{2}$} & \multicolumn{4}{|l|}{1.17} & \multicolumn{2}{|c|}{1.17} \\
\hline \multicolumn{5}{|l|}{ Solar absorber area $A_{\text {sol }}, \mathrm{m}^{2}$} & \multicolumn{4}{|l|}{1.08} & \multicolumn{2}{|c|}{1.08} \\
\hline \multicolumn{5}{|l|}{ Wick area per layer, $\mathrm{m}^{2}$} & \multicolumn{4}{|c|}{$0.278(580 \mathrm{~mm} \times 480 \mathrm{~mm})$} & \multicolumn{2}{|c|}{$5.81(\mathrm{H} 0.7 \mathrm{~m} \times \mathrm{L} 8.3 \mathrm{~m})$} \\
\hline \multicolumn{5}{|l|}{ Still cell gap, mm } & \multicolumn{4}{|c|}{6} & \multicolumn{2}{|c|}{7} \\
\hline \multirow{2}{*}{\multicolumn{5}{|c|}{$\begin{array}{l}\text { Number of effects } \\
\text { Total evaporating surface area } A_{\text {evp }}, \mathrm{m}^{2}\end{array}$}} & \multirow{2}{*}{\multicolumn{4}{|c|}{$\begin{array}{l}18 \\
10.02\end{array}$}} & \multirow{2}{*}{\multicolumn{2}{|c|}{14 (spiraled) }} \\
\hline & & & & & & & & & & × $8.25 \mathrm{~m}$ spiraled) \\
\hline \multicolumn{11}{|c|}{ Comparison between MEDS-1L [18] and MEDS-sp both from the regression lines of test data } \\
\hline \multirow[t]{2}{*}{$\begin{array}{l}\text { Daily-total solar irradiation } \\
\text { on glass cover } H_{T}, \mathrm{MJ} \mathrm{m}^{-2} \mathrm{~d}^{-1}\end{array}$} & \multirow{2}{*}{$\begin{array}{l}\text { Water } \\
\text { productivity } \\
D_{w}, \mathrm{~kg} \mathrm{~d}^{-1}\end{array}$} & \multicolumn{3}{|c|}{$\begin{array}{l}\text { Daily water productivity } \\
\text { per unit area, } \mathrm{kg} \mathrm{m}^{-2} \mathrm{~d}^{-1}\end{array}$} & \multirow[t]{2}{*}{$\begin{array}{l}\text { Solar distillation } \\
\text { efficiency } R_{\text {cov }}\end{array}$} & \multirow{2}{*}{$\begin{array}{l}\text { Water } \\
\text { productivity } \\
D_{w}, \mathrm{~kg} \mathrm{~d}^{-1}\end{array}$} & \multicolumn{3}{|c|}{$\begin{array}{l}\text { Daily water productivity } \\
\text { per unit area, } \mathrm{kg} \mathrm{m}^{-2} \mathrm{~d}^{-1}\end{array}$} & \multirow[t]{2}{*}{$\begin{array}{l}\text { Solar distillation } \\
\text { efficiency } R_{\text {cov }}\end{array}$} \\
\hline & & $M_{\text {cov }}$ & $M_{\text {sol }}$ & $M_{e v p}$ & & & $M_{\text {cov }}$ & $M_{\text {sol }}$ & $M_{\text {evp }}$ & \\
\hline 15.2 & 15.4 & 12.98 & 14.06 & 1.52 & 1.81 & 21.9 & $\begin{array}{l}19.13 \\
(+47 \%)\end{array}$ & $\begin{array}{l}22.38 \\
(+59 \%)\end{array}$ & $\begin{array}{l}4.39 \\
(189 \%)\end{array}$ & $\begin{array}{l}2.61 \\
(+44 \%)\end{array}$ \\
\hline 19.6 & 20.7 & 17.73 & 19.20 & 2.09 & 2.11 & 29.9 & $\begin{array}{l}26.01 \\
(+47 \%)\end{array}$ & $\begin{array}{l}30.43 \\
(+58 \%)\end{array}$ & $\begin{array}{l}5.97 \\
(+188 \%)\end{array}$ & $\begin{array}{l}3.04 \\
(+44 \%)\end{array}$ \\
\hline 20.7 & 22.0 & 18.91 & 20.49 & 2.21 & 2.18 & 31.9 & $\begin{array}{l}27.73 \\
(+47 \%)\end{array}$ & $\begin{array}{l}32.44 \\
(+58 \%)\end{array}$ & $\begin{array}{l}6.36 \\
(+187 \%)\end{array}$ & $\begin{array}{l}3.15 \\
(+44 \%)\end{array}$ \\
\hline \multirow[t]{2}{*}{22.4} & 24.1 & 20.75 & 22.48 & 2.43 & 2.29 & 35.0 & $\begin{array}{l}30.39 \\
(+46 \%)\end{array}$ & $\begin{array}{l}35.55 \\
(+58 \%)\end{array}$ & $\begin{array}{l}6.97 \\
(+187 \%)\end{array}$ & $\begin{array}{l}3.30 \\
(+44 \%)\end{array}$ \\
\hline & & & & & & Average improvement & $+47 \%$ & $+59 \%$ & $+188 \%$ & $+44 \%$ \\
\hline
\end{tabular}

sMDU. Table 4 shows that at the same heat input from the solar collector, the heat flux through still cell in MEDS-sp (assumed uniform) is about one ninth of MEDS-1L. Besides, the larger evaporating and condensing area at the outer cell of sMDU may have lower transport resistance and increase heat and mass transfer at the outer cells. This may explain why the performance of MEDS-sp is much better. The phenomenon of heat and mass transfer in the spiral still cell is quite complicated. Further researches are still needed to understand the detailed mechanism.

Nakatake and Tanaka [20] designed a horizontal concentric cylindrical MDU heated by frictional heat generated by wind energy, through a liquid heat medium. It is similar to sMDU, however, the diffusion cells are in concentric cylindrical shape which allows no lateral diffusion and the manufacture is more difficult than sMDU.
The wick peel-off problem in MEDS-sp is solved since the curvedstructure of spiraled plate/wick creates a stretching force in the wick material and a tight contact between the heating plate and the wick.

The feeding rate of MEDS-sp was set at $120-130 \mathrm{~g} / \mathrm{min}$, about twice of the maximum production rate of the still, to avoid bubble formation and peer-off of wick material as described in Section 2.1. That is, the flow ratio of inlet water to pure water is in the range of 1.3-3.0. The feeding flow is fixed by regulating a valve manually, since the productivity of MEDS-sp can be optimized with respect to variation of solar radiation through feed flow rate control. Metering pump associated with a controller can be used. In this case, MEDS-sp will not run autonomously and requires electrical energy to drive the pump.

The pure water contamination was not found in the present test since the feeding rate was controlled carefully such that no bubble

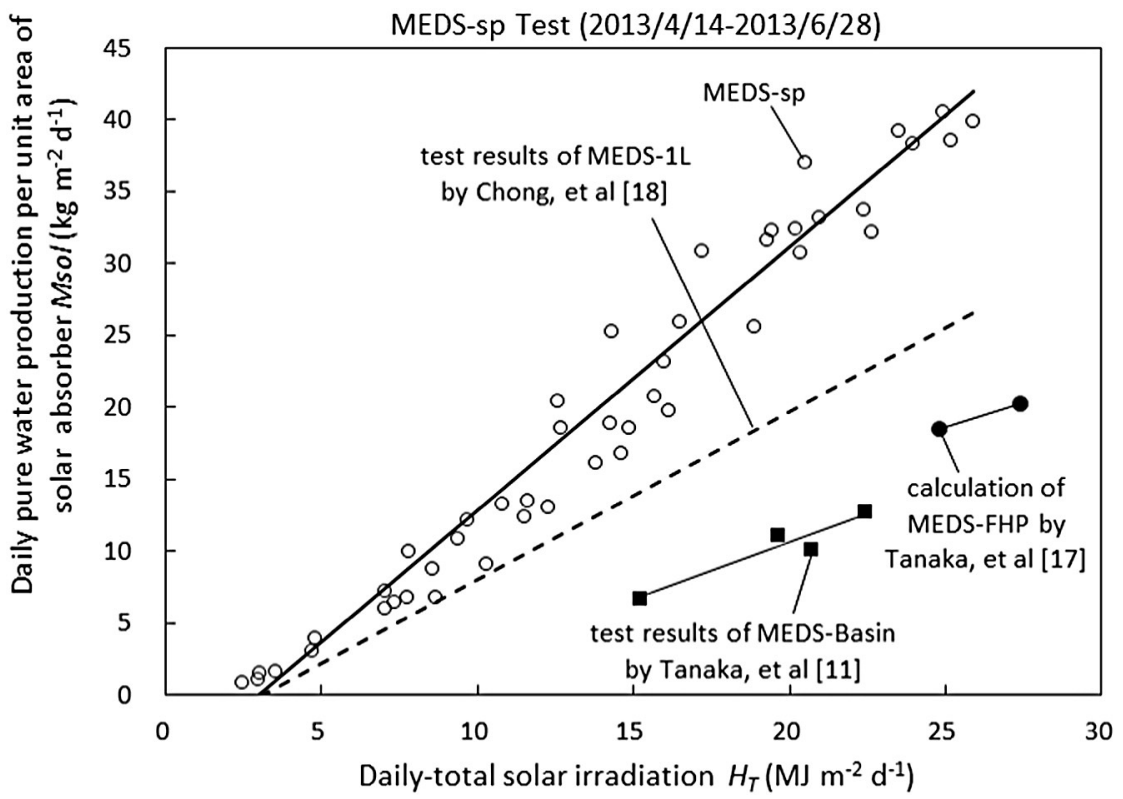

Fig. 12. Comparison of water productivity per unit area of solar absorber. 


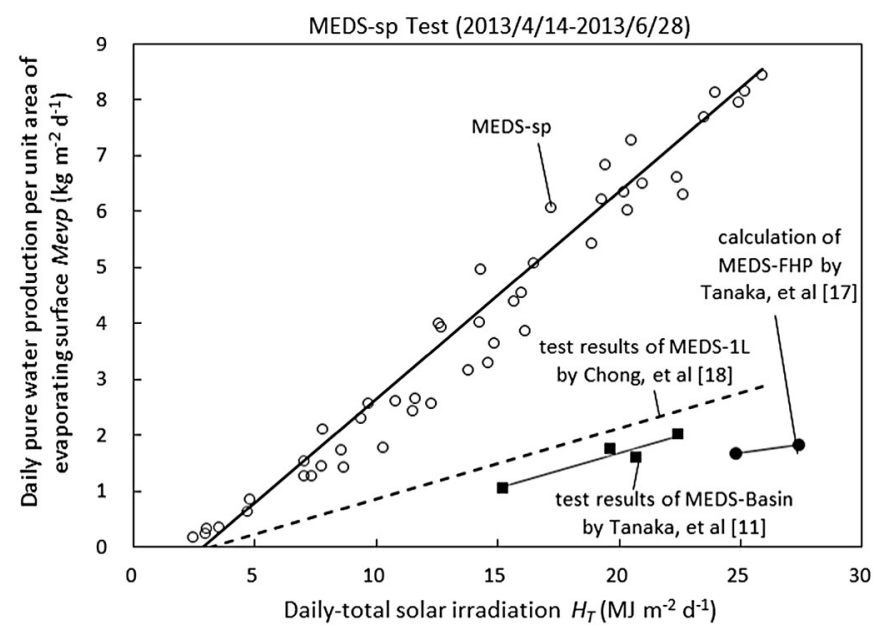

Fig. 13. Comparison of water productivity per unit area of evaporating surface.

formation and dry-out occurs in the wick. A repeated test using dyed (colored) water in feed flow was performed. No contamination in pure water was observed.

No leakage of brine into pure water was observed also since the flow path of sMDU is carefully designed and manufactured as described in Section 2.1. We also observed no flow to the pure water collector at night.

The effect of wick scaling on performance needs a long-term observation. For the test period of MEDS-sp in about 3 months, we observed no significant performance degradation. Nevertheless, a regular replacement of wick material in sMDU is necessary. The modular-type design of the present sMDU makes it easy for replacement of wick material.

Loss of feeding water in sMDU due to water supply failure needs to be carefully treated in order to avoid burn-out of wick and damage of heat pipe due to very high temperature flow from the vacuum-tube solar collector in sunny days.

The design of sMDU is an open-type in spiral-shape still cell. That is, the cell is open to the atmosphere along pure water collection path although there is a vapor seal design. The maximum operating temperature of sMDU is thus $100^{\circ} \mathrm{C}$. The working fluid used in the heat pipe is water which has a lower pressure at operating temperature below $100{ }^{\circ} \mathrm{C}$. This improves the safety of the product.

It has been shown that a MEDS-sp coupled with one set of solar collector $\left(1.08 \mathrm{~m}^{2}\right)$ can produce pure water of $40.6 \mathrm{~kg}$ per day maximum at

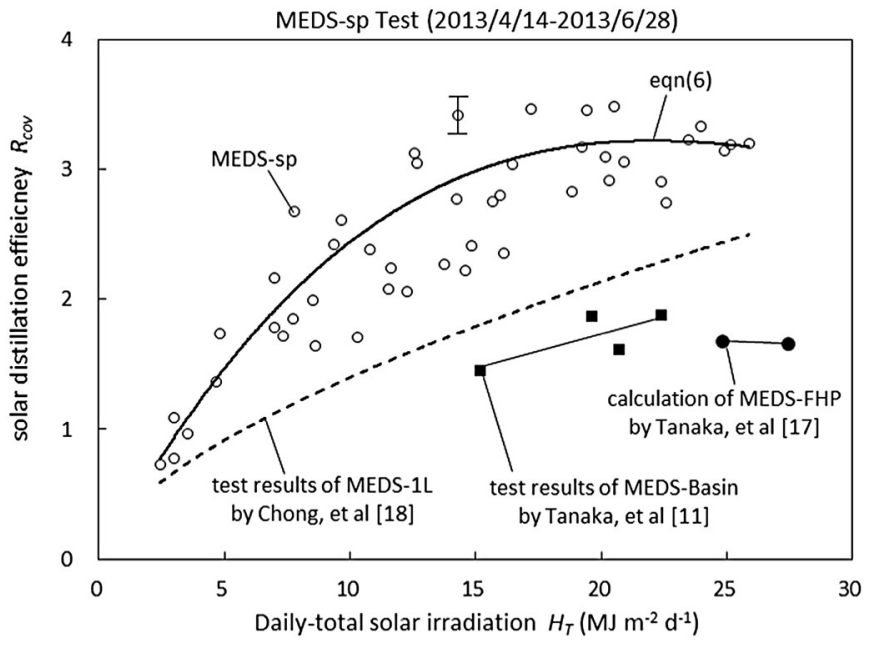

Fig. 14. Solar distillation efficiency comparison of MEDS-sp with other MEDS $[11,17,18]$.

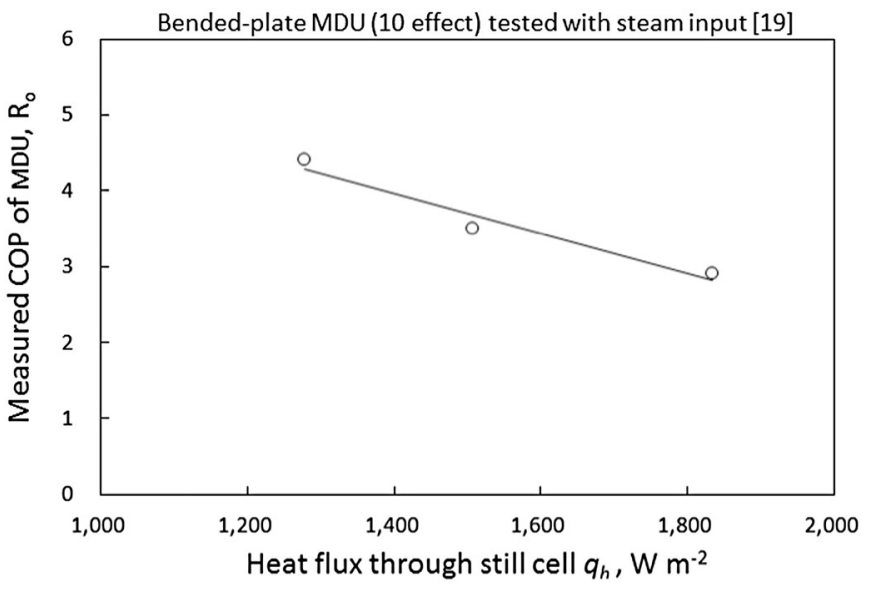

Fig. 15. Measured COP of MDU using steam [19].

sunny weather (Fig. 16), which is enough to supply drinking water for about 12 people a day.

The purchase price of vacuum-tube solar collector used in MEDS-sp is around USD400 per set (absorber area $1.08 \mathrm{~m}^{2}$ ) which is about two times of flat-plate collector.

The manufacture cost of sMDU is also lower than MEDS-1L [18] since the area of evaporating surface used is about half of MEDS-1L and the spiral design makes the production much easier and cheaper.

Since the condenser section of heat pipe in MEDS-sp is a cylindrical shape and the working fluid of heat pipe is water, the condenser can be made from plastic or ceramic material. The porous heating surface made from sintering process of plastic or ceramic material can be separately attached on the condenser cylinder. This will simplify the maintenance. The manufacture cost of sMDU including condenser is around USD120. It is expected that the mass production cost of the whole MEDS-sp will be around USD750. The cost can be further reduced if the design of MEDS-sp is optimized with optimal layers of spiral cell.

One of the most important features of MEDS-sp is that, it is operated at ambient pressure without high-pressure or vacuum component in the system. Maintenance is thus quite simple and the cost is low.

The spiral design of sMDU causes no peel-off of wick and pure water contamination. No performance deterioration was observed in a continuous operation for 3 months.

\section{Conclusions}

The present study develops a MEDS with a novel spiral-shape still cell in MDU. Beside the radial vapor diffusion in the direction perpendicular to the plate, vapor can also be diffused laterally inside the gap to enhance the water evaporation and vapor condensation processes. That is, the vapor flow generated by heat input can flow freely and laterally through the spiral channel down to the end when solar heat input is high.

The test results of MEDS-sp built with 14-effect in the present study show that in sunny weather, both of the solar collectors supply temperature $T_{h}$ and the first heating plate temperature $T_{p 1}$ keeps at $100{ }^{\circ} \mathrm{C}$ at solar radiation of $I_{T}=600-750 \mathrm{~W} \mathrm{~m}^{-2} . T_{h}$ and $T_{p 1}$ reach $70-90{ }^{\circ} \mathrm{C}$ and

Table 4

Calculation of heat flux $q_{h}$ through still cell in MEDS-1L and MEDS-sp.

\begin{tabular}{lllc}
\hline Solar irradiation $I_{T}, \mathrm{~W} \mathrm{~m}^{-2}$ & Heat input to MDU, W & \multicolumn{2}{l}{$\begin{array}{l}\text { Heat flux through still } \\
\text { cell } q_{h}, \mathrm{~W} \mathrm{~m}^{-2}\end{array}$} \\
\cline { 3 - 4 } & & MEDS-1L & MEDS-sp \\
\hline 600 & 324 & 583 & 64 \\
800 & 432 & 777 & 85 \\
1000 & 540 & 971 & 106 \\
\hline
\end{tabular}




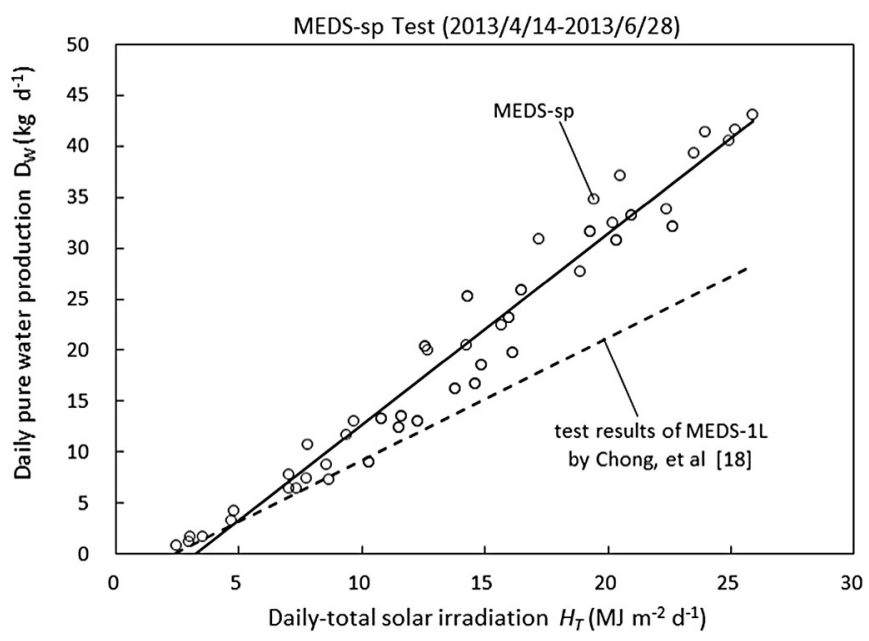

Fig. 16. Comparison of daily water productivity of MEDS-sp with MEDS-1L [18].

53-88 ${ }^{\circ} \mathrm{C}$, respectively, at $I_{T}=400 \mathrm{~W} \mathrm{~m}^{-2}$, depending on the cold/hot status of sMDU due to thermal mass effect. The measured highest pure water production $\left(D_{w}\right)$ is $40.6 \mathrm{~kg} \mathrm{~d}^{-1}$.

The measured highest productivity per unit area of glass cover, solar absorber, and evaporating surface $\left(M_{c o v}, M_{\text {sol }}\right.$, and $\left.M_{\text {evp }}\right)$ is $47 \%, 59 \%$, and $188 \%$ higher than MEDS-1L [18], respectively, and is much higher than the published results.

The measured solar distillation efficiency $R_{\text {cov }}$ of MEDS-sp is 2.0-3.5, about 44\% higher than MEDS-1L (1.5-2.4). This resulted from the enhanced diffusion process in the spiraled still cell of sMDU due to lateral diffusion. Besides, the larger evaporating and condensing area at the outer cell may increase heat and mass transfer at the outer cell.

\section{Nomenclatures}

$A_{\text {cov }} \quad$ total area of glass cover in MEDS, $\mathrm{m}^{2}$

$A_{\text {evp }} \quad$ total evaporating surface area for vaporization in MDU, $\mathrm{m}^{2}$

$A_{\text {sol }} \quad$ total solar absorber area for collecting solar energy, $\mathrm{m}^{2}$

$D_{w} \quad$ daily pre water production, $\mathrm{kg} \mathrm{d}^{-1}$

$h_{f g} \quad$ latent heat of water, $\mathrm{kJ} \mathrm{kg}^{-1}$

$H_{T} \quad$ daily-total solar irradiation on glass cover, $\mathrm{MJ} \mathrm{m} \mathrm{m}^{-2} \mathrm{~d}^{-1}$

$I_{T} \quad$ instantaneous solar irradiation on glass cover, $\mathrm{W} \mathrm{m}^{-2}$

$M_{\text {cov }} \quad$ daily-total pure water production per unit area of glass cover defined in Eq. (1), $\mathrm{kg} \mathrm{d}^{-1} \mathrm{~m}^{-2}$

$M_{\text {evp }} \quad$ daily-total pure water production per unit area of evaporating surface defined in Eq. (3), $\mathrm{kg} \mathrm{d}^{-1} \mathrm{~m}^{-2}$

$M_{\text {sol }} \quad$ daily-total pure water production per unit area of solar absorber defined in Eq. (2), $\mathrm{kg} \mathrm{d}^{-1} \mathrm{~m}^{-2}$

$q_{h} \quad$ heat flux through still cell, $\mathrm{W} \mathrm{m} \mathrm{m}^{-2}$

$R_{\text {cov }} \quad$ daily-total solar distillation efficiency (COP) of MEDS, defined in Eq. (4)

$R_{o} \quad$ daily-total distillation efficiency (COP) of MDU, defined in Eq. (6)

$T_{a} \quad$ ambient temperature, ${ }^{\circ} \mathrm{C}$

$T_{h} \quad$ solar collector supply temperature to MDU, ${ }^{\circ} \mathrm{C}$
$T_{p 1} \quad$ MDU first-plate temperature, ${ }^{\circ} \mathrm{C}$

$w_{D w} \quad$ relative measurement uncertainty of daily pure water production $D_{w}$, dimensionless $0-1$

$w_{H T} \quad$ relative measurement uncertainty of daily total solar irradiation $H_{T}$, dimensionless $0-1$

$w_{R} \quad$ relative measurement uncertainty of $R_{\text {cov }}$, Eq. (5), dimensionless $0-1$

\section{Acknowledgement}

This publication is based on work supported by Award No. KUK-C1014-12, made by King Abdullah University of Science and Technology (KAUST), Saudi Arabia, and by Grant No. NSC101-2221-E-002-067MY2, Ministry of Science and Technology, Taiwan.

\section{References}

[1] M.A.S. Malik, G.N. Tiwari, A. Kumar, M.S. Sodha, Solar Distillation, Pergamon Press, Oxford, 1982. 59-71.

[2] K. Tanaka, Doctoral thesis, Keio University, Yokohama, Japan, 1985, pp. 1-26.

[3] H. Tanaka, Doctoral thesis, University of the Ryukyus, Okinawa, Japan, 2001, 4-24, 33-46.

[4] R.V. Dunkle, Solar water distillation: the roof type still and a multiple effect diffusion still, International Heat Transfer Conference, Part 5, University of Colorado, 1961, pp. 895-902.

[5] P.I. Cooper, J.A. Appleyard, The construction and performance of a three effect wick type tilted solar still, Sun Work 12 (1) (1967) 4-8.

[6] M.M. Elsayed, K. Fathalah, J. Shams, J. Sabbagh, Performance of multiple effect diffusion stills, Desalination 51 (2) (1984) 183-199.

[7] S. Toyama, T. Aragaki, K. Murase, K. Tsumura, Simulation of a multiple-effect solar distillator, Desalination 45 (1983) 101-108.

[8] S. Toyama, T. Aragaki, H.M. Salah, K. Murase, Dynamic characteristics of a multistage thermal diffusion type solar Distillator, Desalination 67 (1987) 21-32.

[9] H.M. Yeh, S.W. Tsai, N.T. Ma, Proc. 22nd Intersociety Energy Conversion Engineering Conference, August 10-14, Philadelphia, Pennsylvania, 4, American Institute of Aeronautics and Astronautics, New York, 1987, pp. 1723-1727.

[10] B. Bouchekima, B. Gros, R. Ouahes, M. Diboun, Performance study of the capillary film solar distiller, Desalination 116 (1998) 185-192.

[11] H. Tanaka, T. Nosoko, T. Nagata, Experimental study of basin-type, multiple-effect, diffusion-coupled solar still, Desalination 150 (2) (November 1 2002) 131-144.

[12] T. Nosoko, T. Kinjo, C.D. Park, Theoretical analysis of a multiple-effect diffusion still producing highly concentrated seawater, Desalination 180 (2005) 33-45.

[13] Development of Desalination Technology Using Multiple-Effect Diffusion Solar Distillation Method, Annual report, Water-Reuse Center Foundation, 1985.

[14] Hiroshi Tanaka, Experimental study of vertical multiple-effect diffusion solar still coupled with a flat plate reflector, Desalination 249 (2009) 34-40.

[15] Hiroshi Tanaka, Yasuhito Nakatake, A vertical multiple-effect diffusion-type solar still coupled with a heat-pipe solar collector, Desalination 160 (2004) 195-205.

[16] Hiroshi Tanaka, Yasuhito Nakatake, Masahito Tanaka, Indoor experiments of the vertical multiple-effect diffusion-type solar still coupled with a heat-pipe solar collector, Desalination 177 (2005) 291-302.

[17] Hiroshi Tanaka, Yasuhito Nakatake, Katsuhiro Watanabe, Parametric study on a vertical multiple-effect diffusion-type solar still coupled with a heat-pipe solar collector, Desalination 171 (2004) 243-255.

[18] Tze-Ling Chong, Bin-Juine Huang, Wu. Po-Hsien, Yeong-Chuan Kao, Multiple-effect diffusion solar still coupled with vacuum-tube collector and heat pipe, Desalination 347 (2014) 66-76.

[19] Bin-Juine Huang, Tze-Ling Chong, Hsien-Shun Chang, Wu. Po-Hsien, Yeong-Chuan Kao, Solar Distillation System Based on Multiple-Effect Diffusion Type Still, J. Sustain. Dev. Energy Water Environ. Syst. 2 (1) (2014) 41-50.

[20] Yasuhito Nakatake, Hiroshi Tanaka, A new maritime lifesaving distiller driven by wind, Desalination 177 (2005) 31-42.

[21] Philip Bevington, D. Keith Robinson, Data Reduction and Error Analysis for the Physical Sciences, 2nd ed. McGraw-Hill, Inc, 1992. (Chapter 3). 